\title{
Shashi Deshpande's the Intrusion and Other Stories: an Applause of Womanhood
}

\section{Dr. Rajesh H. Mehta}

\begin{abstract}
:
Shashi Deshpande, the recipient of 1990 SahityaAkademi Award, penned her first short story collection The Legacy and Other Stories in the year 1978. She started writing short stories at a mature age of thirty to record her trip to England with her husband. Since then, she has published five collections of short stories. The fifth collection The Intrusion and Other Stories got published in 1993 when she was already an established Indian writer writing in English. The anthology narrates nineteen stories of women protagonists. All the protagonists of these stories have one or the other wish to fulfil, during the course of the action; they struggle hard to fulfil their dreams and aspirations. The author captures the touching knots of these women, either young or old, struggling against disappointment, failed love, and the death of their near ones. At times funny, at times disturbing, these stories are realistic record of their heroic and moving endeavour to rise above their limitations.
\end{abstract}

Keywords: Indian English, Short Story, Feminism, Womanhood

\section{Preamble:}

Shashi Deshpande is considered as one of the acclaimed (women) writers of Indian English in the post-independence Indian English Literature. She was born in Dharwad, Karnataka. Her father Adya Rangacharya was a renowned dramatist of Kannada. In her stories, she records her natural talent of storytelling. All her stories are gripping and holding the readers for refreshing experience. Mostly her writings focus upon the concerns of educated middle class women in Indian society. She writes with the Indian readers in mind, wherein she projects the frustrations as well 
as fun of women in our social structure presenting the women's world as it is, from inside.

Shashi Deshpande has studied journalism and her initial writings were in the form of articles on social issues of urban Indian society in the famous magazine Onlooker. As a fiction writer, she penned her first collection of short stories in the year 1978 (The Legacy and Other Stories). She has since than published nearly half a dozen short story collections and a dozen of novels. Her fifth short story collection The Intrusion and Other Stories (1993) is about the relationships that women have with others - men as well as other women. Shashi Deshpande is a woman writer writing about women but it is hoped not only for women readers. If women's writing (or writing by women) can or does appeal only to women readers, then there is a serious danger of 'ghettoization', of such writing being left only on the periphery, of always having the tag of 'women's writing' and never becoming 'writing' without any adjective to describe it. As Lakshmi Kannan has rightly put it,

For a woman, her works are no less a process of self-actualization as her life is. In both, she wrestles with a host of obstinate paradigms and syndromes, precipitated by not just the myths, legends or the collective memory of the inherent conservative elements within a community, but equally with the ones thrown up by the movement of feminism itself. (31)

Deshpande's collection The Intrusion and Other Stories possesses nineteen stories in it. Almost all stories have female protagonists at the centre - analysing, remembering, recapitulating or evaluating a relationship. And by and large, it is a family relationship with another female - a mother, daughter or granddaughter - or a male - a husband or a father. Surprisingly, there is no sibling sister-brother relationship though a couple of stories do have a sister-sister relationship. Deshpande poignantly describes the instinctive reaching out of a woman for the other in times of pain, sorrow, fear, despondency etc. in some of the stories.

\section{Thematic Preoccupations:}

The stories in the collection provide a wide range of issues, from ancient time of Mahabharata to present day challenges like migrating abroad in search of employment. There are three stories, wherein the characters from Mahabharata Amba, Kunti, and Draupadi are recreated. These mythical characters provide a broad time span along with the intensity of her narration that engulfs the reader into 
the 'inner rooms'. Here, Deshpande meticulously highlights the very foundation of woman's image of a mother, daughter, wife or sister, which is the result of the collective consciousness of a society, constructed out of mythic characters, rituals, legends, folklore, and perception of the past, resulting into that long silence. Myths, legends, and folklores are deeply engrained in the Indian psyche, which creates the mother image of 'a binding vine'. She doesn't agree with the idealisation of motherhood - the false and sentimental notes that accompany it. The stories, The Inner Rooms, The Last Enemy and Hear me Sanjaya... are the parallels to link the long silence with its roots and shadows spreading beyond time and space.

The major concerns of the writer that might seem to be the outcome of modern shifts in remaining sixteen stories needs to be studied to trace its roots. A brief review of multitudinous problems of each middle-class woman character from the collection will help to trace the writer's serious quest to break the silence. These are the issues, which cannot be spoken by an individual to disturb ones social sphere. Such as: an old lady who thinks 'We have lived too long.' (IOS 79) in The First Lady'. A woman conscious of ignorance by the husband and maturing daughter, 'I don't have the key to open up this beautiful child, though she is mine.' (IOS 11)in Why a Robin. The state of the young trio of working parents living in a single room - trapped to ask themselves an eternal question 'Can You Here Silence?' Disturbing dark story of a school going girl, victim of a rape in It Was Dark.

In It Was Dark, a 14-year old rape victim attempts come up to terms with the terrifying experience. The mother attempts to help her come out of the trauma but the young girl continues to stare at the ceiling, 'with blank and unseeing eyes,' (ISO 32) isolated and alienated by her experience. In her novel The Binding Vine, Shashi Deshpande had juxtaposed rape in marriage and outside it - the rape of Kalpana and Mira. Here too, the mother thinks of her wedding night when she remembered her mother's words, 'You must submit...' (ISO 32) and it was only submission that had made things easier. The child finally relates to the mother and allows her eyes to shift their focus from the ceiling on to her mother. The unnamed 14-year old becomes a victim of the worst outrage against the female body-rape. To the mother it seems as if being a female meant building walls with negatives around oneself: 
Don't - don't - don't - you're female. They taught me to build a wall around myself with negatives from childhood. And then suddenly, when I got married, they told me to break the walls down. To behave as if it had never been. And my husband too - how completely his disregard of the wall had been; I had felt totally vulnerable, wholly defenceless. I won't let my daughter live behind walls, I had thought. (ISO 31)

Form the outrage against the female body, Deshpande moves on to women's sexuality, motherhood and the choice to abort one's child. For eons in our patriarchal society it has been the prerogative of the male to decide whether or not a child should be born. In Death of a Child, the protagonist decides not to have a child that she cannot welcome into this harsh world. She feels, 'The third time in less than four years. It isn't fair.'(IOS 44) Sita in Anita Desai's novel Where Shall We Go This Summer? wanted to retain her child in the womb and not to allow it to be born in this violent-ridden, callous, loveless world. Here the mother decides that she will not have a third child because 'Children stifle your personality. You become a mother, nothing more.' (IOS 45) She feels quite strongly about it, about being stifled, about being pushed into a pre-ordained role: 'I feel trapped. I feel like animal... I cannot imagine that the main purpose of my life is to breed.' (ISO 44) And so, against the half-hearted attempts of her husband to convince her, she decides to have an MTP medical termination of pregnancy. The woman makes a choice that she is the master of her body and that the final word should be hers. And so, she decides to have control of her body, her life and her destiny. Yet, she is confused and Deshpande portrays realistically the ambivalent feelings of the woman towards her own decision:

I feel heaviness in my own breasts. There is a hollow feeling within me. I'm filled with strange thoughts. Where have I heard that, after an amputation, a person continues to feel that amputated limb? It itches, it hurts, it exists. Now, like a phantom limb, my child seems to cling to me. Now, when he does not exist, he asserts himself. I am conscious of a piercing pain in the place that he had filled. Grief becomes real. I swing like a monstrous pendulum, between grief, guilt and shame. Guilt conquers. I welcome it and shoulder the burden with a masochistic fervour. But for me, my child would have lived. I try to delude myself into thinking it is fate. But I do not believe in fate. Only in inevitability. And this was not inevitable. But, yes, it was. I could have done no other thing, acted in no other way. (ISO 50)

The anonymity of many of these characters in their being unnamed gives them their universality too. The need to reach out to a child, one's own child, is a common thread linking many of the short stories in the collection. In The Cruelty Game, the 
recently widowed Pramila Auntie places her child Sharu's needs even above her own personal sorrow. In spite of all the criticism she decides to celebrate her daughter's birthday, while in My Beloved Charioteer, Ajji finds it impossible to reach out to her daughter Aarti who has isolated herself totally after the sudden death of her husband. The mother here feels helpless at the silence of her daughter.

Nine months I carried this daughter of mine in my body. I felt ever beat of her heart, every movement of her limbs within me. But - and my doctor told me this then - my pains and shocks could never penetrate to her, she was insulated against them. Even now, she is protected from my pains, even now. I have no protection against her pains. I suffer with her but, like all my other emotions, it is a futile suffering. For I cannot help her. I can only fumble and blunder and make things worse. (IOS 53)

It seems as if the mother then looks to the next generation for Deshpande presents a bonding of the grandmother with the grandchild in both And Then? As well as My Beloved Charioteer.

The issues brought forward from the above short stories are not all, it is like churning the vicious ocean, and the writer's exercise to extract the dark is unfathomable. The remaining three stories that take us to the remote past and yet surface so close that they equip the writer as well as readers clear their perspectives. The most consciously devised story, Hear meSanjaya... Kunti the wisest, boldest honoured mother figure reminiscences breathlessly with Sanjay the Mahabharata epic story, and the character of Kunti provides a vast time span to the writer's concerns in the above discussed story. Pritha or Kunti thinking of her past and present where she feels foolish clinging to the roles of a mother but feels the freedom not wanting anything for her or her children anymore after they are dead. Revealing her real self before Sanjay she draws us into the inner rooms of woman's consciousness recollecting her becoming Kunti from Pritha. Meeting her illegitimate son Karna, who is not ready to call her mother. Repenting to have been unjust to Draupadi. How timid Kunti is the very image that sets an example of Indian womanhood. Shashi Deshpande subverts the very image of mother that she recreates by Kunti's uninterruptible eloquence and not an internal monologue.

Further in The Inner Rooms Amba the princess of Kashi becomes the symbol of a woman rejected, dejected, humiliated, and ridiculed by the might of mighty Bhishma, and finds a chance to have her own choice to go to her lover but is not accepted 
shows the plight of a woman that reoccurs in her works. The issue is of a disregarded woman, treated as a pawn due to man's foolish rules. She is made to rise to as high as to challenge Bhishma, a symbol of male power and a celebrate but was let down just because she was a woman he could not fight her! She is regarded free in the end as she was neither a daughter, nor a wife, nor a mother but only Amba. Just as in case of Kunti in Hear meSanjaya... says:

You know, Sanjaya, seeing the animals here, I have begun thinking that we are wrong, we are foolish, in clinging to our roles for so long. Does a grown deer seek its mother? At some time the bond should snap, it should be over. That is natural, that is wiser. No? You don't agree? But then one should not live long enough to see the sight I saw. These tired old men my sons, I thought? It frightened me ... (IOS 93)

Both Amba and Kunti meet the same fate as most of her characters in the short stories with no solution but realising their freedom by meeting an end to their active lives. All the issues that rise from the earlier stories draw parallel from these epic characters.

Shashi Deshpande who does not approve of her being labelled a feminist or categorised as a 'woman writer', accepts herself as feminist in person. She wrote short stories in early stage of her creative career before writing any of her widely read novels. The study of her short stories proves her competency and awareness for which she has committed herself. The strategy she employs in The Intrusion and Other Stories swallows the reader in the inner rooms of her perception as a woman to present the wide range of issues projected and interrelated.

\section{Conclusion:}

In delineating the relationships of women to society and societal norms, Deshpande subtly interweaves the stigma attached to womanhood through these stories. The collection portrays women attempting to break out of the pre-ordained, pre-defined roles. Not all of them succeed but Deshpande clearly suggests that a beginning has been made. With compassion, she delineates realistically the condition of women in India in current time. 


\section{References:}

Deshpande, Shashi. The Intrusion and Other Stories, New Delhi, Penguin India, 1993.

Kannan, Lakshmi. "To Grow or not to Grow". Indian Feminisms, Ed. Jasbir Jain and

Avadhesh Kumar Singh. New Delhi: Creative Books, 2001.

\section{Dr. Rajesh H. Mehta}

Associate Professor

Department of English, Smt. J. J. Kundalia Commerce College, Rajkot.

rhmehtasir@gmail.com 